\title{
COMPARATIVE ANALYSIS OF LATE RESULTS OF CERVICAL ESOPHAGOGASTRIC ANASTOMOSIS BY MANUAL AND MECHANICAL SUTURE IN PATIENTS SUBMITTED TO ESOPHAGEAL MUCOSECTOMY THROUGH ADVANCED MEGAESOPHAGUS
}

Análise comparativa dos resultados em longo prazo da anastomose esofagogástrica cervical pela sutura manual e mecânica em pacientes submetidos à mucosectomia esofágica por megaesôfago avançado

José Luis Braga de AQUINO', Vania Aparecida LEANDRO-MERHI ${ }^{1}$ José Alexandre MENDONÇA ${ }^{1}$,

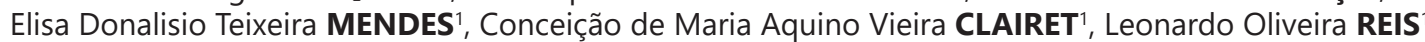

How to cite this article: Aquino JLB, Leandro-Mehri VA, Mendonça JA, Mendes FDT, Clairet CMAV, Reis LO. Comparative analysis of late results of cervical esophagogastric anastomosis by manual and mechanical suture in patients submitted to esophageal mucosectomy through advanced megaesophagus. ABCD Arq Bras Cir Dig. 2019;32(4):e1462. DOI: /10.1590/0102-672020190001e1462

From the ${ }^{1}$ Programa de Pós-Graduação em Ciências da Saúde, Pontifícia Universidade Católica de Campinas (Graduate Program in Health Sciences, Pontifical Catholic University of Campinas), Campinas, SP, Brazil.

HEADINGS - Esophageal achalasia Anastomosis, surgical. Suture techniques.
ABSTRACT - Background: Among the anastomoses of the gastrointestinal tract, those of the esophagus are of special interest due to several anatomical or even general peculiarities. Aim: Evaluate retrospectively the results comparing mechanical vs. manual suture at cervical esophagogastric anastomosis in megaesophagus treatment. Methods: Were included 92 patients diagnosed with advanced megaesophagus with clinical conditions to undergo the surgery. All underwent esophageal mucosectomy, performing anastomosis of the esophagus stump with the gastric tube at the cervical level. In order to make this anastomosis, the patients were divided into two groups: group $A(n=53)$ with circular mechanical suture, lateral end; group $B(n=39)$ with manual suture in two sides, lateral end. In the postoperative period, an early evaluation was performed, analyzing local and systemic complications and late (average 5.6 y) analyzing deglutition. Results: Early evaluation: a) dehiscence of esophagogastric anastomosis $n=5(9.4 \%)$ in group $A$ vs. $n=9(23.0 \%)$ in group $B(p=0.0418) ; b)$ stenosis of esophagogastric anastomosis $n=8(15.1 \%)$ in group $A$ vs. $n=15(38.4 \%)$ in group $B(p=0.0105$.); c) pulmonary infection $n=5(9.4 \%)$ in group $A$ vs. $n=3(7.6 \%)$ in group $B(p=1.0000$.$) ; )$ pleural effusion $n=5(9.4 \%)$ in group $A$ vs. $n=6(15.4 \%)$ in group $B(p<0.518)$. Late evaluation showed that $86.4-96 \%$ of the patients presented the criteria 4 and 5 from SAEED, expressing effective swallowing mechanisms without showing significant differences among the groups. Conclusion: Cervical esophagogastric anastomosis by means of mechanical suture is more proper than the manual with lower incidence of local complications and, in the long-term evaluation, regular deglutition was acquired in both suture techniques in equal quality.

\section{Correspondence:}

José Luis Braga de Aquino

E-mail: jlaquino@sigmanet.com.br

Financial source: none

Conflict of interest: none

Received for publication: 26/05/2019 Accepted for publication: 06/08/2019

DESCRITORES - Acalásia esofágica. Anastomose cirúrgica. Técnicas de sutura.
RESUMO - Racional: Das anastomoses do trato gastrointestinal, as do esôfago têm especial interesse devido às varias peculiaridades anatômicas e mesmo sistêmicas. Objetivo: Avaliar retrospectivamente os resultados comparando a sutura mecânica e manual na anastomose esofagogástrica cervical no tratamento do megaesôfago. Métodos: Foram estudados 92 pacientes com diagnóstico de megaesôfago avançado com condições clínicas de serem submetidos à operação. Todos foram submetidos à mucosectomia esofágica, sendo realizada anastomose do coto esofágico com o tubo gástrico no nível cervical. Para a realização desta anastomose, foram divididos em dois grupos: grupo A $(n=53)$ com sutura mecânica circular terminolateral; grupo $B(n=39)$ com sutura manual em dois planos terminolateral. No período pós-operatório foi realizada avaliação precoce, com análise das complicações locais e sistêmicas, e tardia (média 5,6 anos) com análise da deglutição. Resultados: Avaliação precoce: a) deiscência da anastomose esofagogástrica, $n=5(9,4 \%)$ no grupo A vs. $n=9$ $(23,0 \%)$ no grupo $B(p=0.0418)$; $b)$ estenose da anastomose esofagogástrica $n=8(15,1 \%)$ no grupo A vs. $n=15(38,4 \%)$ no grupo $B(p=0.0105)$; $c)$ infecção pulmonar $n=5(9,4 \%)$ no grupo $A$ vs. $n=3$ $(7,6 \%)$ no grupo $B(p=1.000)$; d) derrame pleural $n=5(9,4 \%)$ no grupo $A$ vs. $n=6(15,4 \%)$ no grupo $B(p<0.518)$. A avaliação tardia demonstrou que 86,4 a $96,0 \%$ dos pacientes apresentaram critérios 4 e 5 de SAEED, demonstrando deglutição efetiva e sem diferença significante entre os grupos. Conclusão: A anastomose esofagogástrica pela sutura mecânica é mais adequada que a manual com pequena incidência de complicações locais e, na avaliação em longo prazo, a deglutição demonstrou ser adequada em ambos os grupos e com qualidade semelhante. 


\section{INTRODUCTION}

A mong the anastomoses of the gastrointestinal tract, those of the esophagus are of special interest due to several anatomical or even general peculiarities, which distinguish them from other segments of the digestive tract $5,14,15,18$. Hence, the anastomotic dehiscences in this organ appear with a higher incidence, prolonging the permanence of patients in hospitals as well as increasing hospital costs, causing greater suffering for the patients and showing a relationship with stenosis, which is another obstacle that follows the esophageal surgery ${ }^{5,18}$. On the other hand, the mechanical suture demonstrating more safety, precision and fastness, predisposes to a lower incidence of anastomotic fistula, as it has been demonstrated in the literature, both in benign and malignant diseases, being able to improve the quality of life $2,4,5,9,20,21,30$. This preference can be justified by less ischemia, less extensive tissue necrosis and a more pronounced neoangiogenesis, as has been demonstrated in experimental studies ${ }^{4,15,18,32}$.

In advanced megaesophagus of chagasic origin the disease damages the contractility of the organ due to plexular denervation impairing deglutition, with the consequent malnutrition. Besides, due to the stasis that occurs over the years, it may also induce the development of cancer ${ }^{5,17}$.

As it has been demonstrated by several authors for many years, the best therapy is esophagectomy without thoracotomy ${ }^{13}$, as it acts directly in the physiopathology of this disease, being the transmediastinal technique proposed by Pinotti the most used ${ }^{5,8,22,23}$. More recently with the advent of minimally invasive surgery, this resection can be performed by videolaparoscopy ${ }^{12,29}$. In a more critical analysis; however, it has been demonstrated that transmediastinal esophageal resection is not free from complications which may contribute to greater morbidity in the postoperative $e^{8,10,19}$. This may occur, as the advanced megaesophagus presents periesophagitis leading to the adherence to mediastinal structures predisposing and complications.

This fact stimulated Aquino et al. ${ }^{3,6}$ to propose the technique of esophageal mucosectomy with preservation of the muscular layer and transposition of the stomach into the muscular layer of the esophagus for the reconstruction of the digestive transit and anastomosis of the stomach with the stump of the cervical esophagus by the technique of manual suture. Thus, a lower rate of complications was observed in relation to esophagectomy without thoracotomy, because it did not transgress the mediastinum during dissection of the esophagus.

In another paper, Aquino et al. ${ }^{1}$ demonstrated the advantages of mechanical suture in relation to manual cervical esophagogastric anastomosis due to the small frequency of anastomotic fistula in patients with advanced megaesophagus but submitted only to transmediastinal esophagectomy.

Consequently, the idea to perform this study was emerged, comparing the manual suture and its mechanics to the level of cervical esophagogastric anastomosis in patients submitted to esophageal mucosectomy through advanced megaesophagus.

Therefore, this study aims to demonstrate if the mechanical suture presents advantages over the manual one for attempting to minimize the anastomotic dehiscence and thus provide an earlier and more proper deglutition with potential improvement of the nutritional status.

METHOD

This study was approved by institutional ethics committee under number 1.277.805

\section{Casuistic}

Between January of 1996 to December 2017, 92 patients with advanced megaesophagus were retrospectively evaluated in the Department of Thoracic Surgery, Celso Pierro Hospital, Faculty of Medicine of the Pontifical Catholic University of Campinas, Campinas, SP, Brazil. Among the studied patients, there was a predominance of male patients in $75 \%(n=69)$ with the age ranging from 23 to 63 years old (mean- $48.5 \mathrm{y}$ ).

\section{Clinical data}

All patients reported progressive dysphagia from solids to liquids and weight loss with variable time from 5-15 years, with $85.9 \%(n=79)$ reporting more frequent intermittent regurgitation in the last six to 24 months. From the total $68.4 \%(n=63)$ were smokers of 20 cigarettes/day for a variable time of $12-26$ years, and $55.4 \%(n=51)$ reported be distillate drinkers of 2-5 dose/day for 11-15 years.

Immunofluorescence for Chagas' disease was positive in $90.2 \%(n=83)$. The clinical and nutritional assessment demonstrated weight loss in $20.6 \%(n=19)$, losing more than $10 \%$ of their ideal weight and submitted to nasoenteral probe for a variable time of 18-33 days prior to the surgical procedure.

\section{Diagnostic assessment}

Radiology

In all patients the contrasted esophageal radiological study showed megaesophagus grade III in $41.3 \%(n=38)$ and grade IV in $58.7 \%(n=54)$, according to the classification of Rezende et al. ${ }^{25}$

\section{Endoscopy}

In all patients the exam showed an increase in the diameter of the organ with distal esophagus mucosa presenting grade $\mathrm{A}$ to $\mathrm{C}$ esophagitis in Los Angeles Classification and without evidence of neoplasia in any one.

\section{Manometry}

Was performed in 30.4\% $(n=28)$ demonstrated in all aperistalsis of the esophagus body and decreased relaxation of the esophageal lower sphincter.

\section{Surgical technique}

All patients underwent esophageal mucosectomy with preservation of the muscular layer, according to the technique standardized by Aquino et al. ${ }^{3,6}$. In doing the cervical anastomosis the patients were divided into two groups, $\mathrm{A}$ and $\mathrm{B}$.

In group $A(n=53)$ mechanical suture used circular $\mathrm{DHC}$ $29 \mathrm{~mm}$ device; for this anastomosis the ogive was fixed in the stump of the cervical esophagus and it was introduced through the anterior side of the stomach and attached to the ogive; the anterior side of the stomach, through which the apparatus was introduced, was sutured with the mechanical technique with a $75 \mathrm{~mm}$ linear suture.

In group B $(n=39)$ manual two planes with 3-0 Vicryl $^{\circledR}$ suture was, being the first one continuous and complete in the stomach and esophagus, and the second in separate stitches, seromuscular in the stomach and muscular in the esophagus

\section{Postoperative assessment}

Clinical complications

Especially focused in cardiovascular, respiratory and infectious complications the diagnosis was based on the daily clinical progress with laboratory and imaging exams, when necessary.

\section{Local complications}

They were mainly related to dehiscence and stenosis of 
the anastomosis of the cervical esophagus with the gastric tube with consequent fistula, the diagnosis was clinical due to the exit of gastric and/or salivary secretion by the cervical region until generally the $7^{\text {th }}$ postoperative day. From that day on, without any evidence of fistula, a contrast X-ray was performed to evaluate if there was output of contrast by the anastomosis. When this did not occur, the oral diet was initiated. In relation to anastomosis stenosis, the diagnosis was clinical due to the symptom of dysphagia, especially from the $30^{\text {th }}$ postoperative day and verified by the $X$-ray contrast at the level of the anastomosis and upper digestive endoscopy, to indicate in both examinations whether the anastomosis diameter decreased.

\section{Deglutition}

In the long-term follow-up deglutition was evaluated at $1,3,5$ and 10 years postoperatively, based on Saeed et al. ${ }^{28}$ criteria: 0 = no swallowing; 1 = swallows liquid with difficulty, but does not swallow neither pasty nor solids; $2=$ swallows normal liquid, pasty with difficulty, and does not swallow solids; 3 = swallows liquid and pasty normally, but swallows solids with difficulty; $4=$ swallows liquid and pasty normally, eventual difficulty to swallow solids; $5=$ normal swallowing.

Other symptoms that could be related to the surgical procedure performed, mainly regurgitation, were also assessed.

\section{Statistical analysis}

For comparison, the chi-square test or the exact fisher test, were used when necessary, with a significance level of $5 \%$.

\section{RESULTS}

In the early evaluation up to 30 postoperative days, 14 patients (15.2\%) presented fistula of the esophagogastric anastomosis at the level of the cervical region, being significantly smaller in group $A$ (Table 1). To one patient from this group was indicated early reoperation because presented the leak on the $2^{\text {nd }}$ postoperative day, having extensive drainage of the cervical and mediastinal region; this patient had a good evolution. In the other 13 patients in which anastomosis fistula occurred between the $4^{\text {th }}$ and $7^{\text {th }}$ postoperative days, the treatment was conservative with local drainage of the cervical region and nutritional support with enteral diet by jejunostomy, with the fistula closing between the $14^{\text {th }}$ and $23^{\text {rd }}$ day of postoperative period. Thus, since there was no further digestive secretion through the cervical region, a contrasted X-ray was required. Showing no signs of contrast extravasation to the anastomosis level, oral diet initially liquid with a progressive replacement for pasty and solid, according to the patient's acceptance, was introduced ${ }^{16}$. This orientation was also performed in the other 78 patients who did not present anastomotic fistula, having the oral diet from the $7^{\text {th }}$ postoperative day after confirming that the contrasted $\mathrm{X}$-ray did not indicate extravasation. All accepted the diet well, in a progressive way.

Eight patients $(8.6 \%)$ between the $5^{\text {th }}$ and $9^{\text {th }}$ postoperative day presented pulmonary infection, without significant differences between the groups (Table 1). With the exception of one patient from group B who evolved to death caused by septic shock, all the remaining had positive progress.

Small to medium volume pleural effusion was present in $11(11.9 \%)$ patients, without significant differences between groups (Table 1$)$. In five $(n=3$ from group $A$ and $n=2$ from group $B$ ) it was necessary to drain the thorax leading to a positive outcome; in the remaining patients who presented this complication, the progress was also positive with the proper conservative treatment.

Between the $30^{\text {th }}$ and $48^{\text {th }}$ postoperative day, 23 patients (25\%) began to present the symptom of advanced progressive dysphagia, confirming stenosis of the esophageal anastomosis at the cervical level by contrasted X-ray and upper digestive endoscopy, being significantly greater in group B. All patients underwent endoscopic dilation ranging from 4-15 sessions with a positive progress.

TABLE1 - Comparative analysis of early postoperative complications between suture groups

\begin{tabular}{|cccc} 
& $\begin{array}{c}\text { Group A } \\
(\mathbf{n}=53)\end{array}$ & $\begin{array}{c}\text { Gruop B } \\
(\mathrm{n}=39)\end{array}$ & $\mathrm{p}$ \\
\cline { 2 - 3 } & $\mathbf{n}(\%)$ & $\mathrm{n}(\%)$ & \\
\hline Anastomotic fistula & $5(9.4)$ & $9(23.1)$ & $0.0418 \mathrm{Chi} 2$ \\
\hline Anastomotic stenosis & $8(15.1)$ & $15(38.5)$ & 0.0105 Chi2 \\
\hline Pulmonary infection & $5(9.4)$ & $3(7.7)$ & $1.0000 \mathrm{~F}$ \\
\hline Pleural effusion & $5(9.4)$ & $6(15.4)$ & $0.5182 \mathrm{~F}$ \\
\hline Death & $0(0.0)$ & $1(2.6)$ & $\mathrm{NC}$ \\
\hline
\end{tabular}

$\mathrm{A}=$ mechanical suture; $\mathrm{B}=$ manual suture; $p=$ Fisher's exact test; Chi2 $=$ Chi-square test; NC-not calculated

The mid and long-term assessment were performed in 71 patients, $69.8 \%(n=37)$ from group $A$ and $87.1 \%(n=34)$ from group $B$, with time ranging from 1 to 10 years (mean $5.6 \mathrm{y}$ ).

In relationship to deglutition, $86.4 \%$ to $96.0 \%$ of the patients presented the criteria 4 to 5 from Saeed et al. ${ }^{28}$ with assessment time ranging from 1 to 10 years without presenting significant differences between the two groups (Table 2).

TABLE 2 - Descriptive analysis and comparison of late assessment between suture groups

\begin{tabular}{|c|c|c|c|c|c|c|}
\hline \multirow{2}{*}{ Late assessment } & \multicolumn{2}{|c|}{ A } & \multicolumn{2}{|c|}{ B } & \multirow{2}{*}{\multicolumn{2}{|c|}{$p$}} \\
\hline & $n$ & $\%$ & $n$ & $\%$ & & \\
\hline 1 YEAR -criteria & $n=37$ & & $n=34$ & & 1.0000 & $\mathrm{~F}$ \\
\hline 0 & 0 & 0.0 & 0 & 0.0 & & \\
\hline 1 & 0 & 0.0 & 0 & 0.0 & & \\
\hline 2 & 0 & 0.0 & 0 & 0.0 & & \\
\hline 3 & 3 & 8.1 & 3 & 8.8 & & \\
\hline 4 & 7 & 18.9 & 7 & 20.6 & & \\
\hline 5 & 27 & 73.0 & 24 & 70.6 & & \\
\hline 3 YEAR-criteria & $n=37$ & & $n=34$ & & 0.2354 & $F$ \\
\hline 0 & 0 & 0.0 & 0 & 0.0 & & \\
\hline 1 & 0 & 0.0 & 0 & 0.0 & & \\
\hline 2 & 0 & 0.0 & 0 & 0.0 & & \\
\hline 3 & 3 & 8.1 & 1 & 2.9 & & \\
\hline 4 & 6 & 16.2 & 11 & 32.4 & & \\
\hline 5 & 28 & 75.7 & 22 & 64.7 & & \\
\hline 5 YEAR-criteria & $n=37$ & & $n=34$ & & 0.3753 & $\mathrm{~F}$ \\
\hline 0 & 0 & 0.0 & 0 & 0.0 & & \\
\hline 1 & 0 & 0.0 & 0 & 0.0 & & \\
\hline 2 & 0 & 0.0 & 0 & 0.0 & & \\
\hline 3 & 5 & 13.5 & 4 & 11.8 & & \\
\hline 4 & 10 & 27.0 & 5 & 14.7 & & \\
\hline 5 & 22 & 59.5 & 25 & 73.5 & & \\
\hline 10 YEAR-criteria & $n=37$ & & $n=34$ & & 0.8787 & $\mathrm{~F}$ \\
\hline 0 & 0 & 0.0 & 0 & 0.0 & & \\
\hline 1 & 0 & 0.0 & 0 & 0.0 & & \\
\hline 2 & 0 & 0.0 & 0 & 0.0 & & \\
\hline 3 & 3 & 8.1 & 4 & 11.8 & & \\
\hline 4 & 11 & 29.7 & 9 & 26.5 & & \\
\hline 5 & 23 & 62.2 & 21 & 61.8 & & \\
\hline
\end{tabular}

$A=$ mechanical suture and $B=$ manual suture; $p=$ Fisher's exact test

The intermittent and sporadic regurgitation that was present with not negligible incidence, did not present significant differences between the groups and was controlled with proper food orientation (Table 3). Is evident in this table that two patients, one from each group, presented Barrett's esophagus in the esophageal stump without presenting statistical significance, having the diagnosis been done in the $3^{\text {rd }}$ and $5^{\text {th }}$ postoperative year with these patients being examined periodically with endoscopy. Most patients from both groups reported weight gain. 
TABLE 3 - Late comparative assessment of postoperative between suture groups

\begin{tabular}{|c|c|c|c|c|c|}
\hline & \multicolumn{2}{|c|}{$\begin{array}{l}\text { Group A } \\
(n=37)\end{array}$} & \multicolumn{2}{|c|}{$\begin{array}{c}\text { Group B } \\
(n=34)\end{array}$} & $\mathrm{p}$ \\
\hline & $n$ & $\%$ & $\mathrm{n}$ & $\%$ & \\
\hline Regurgitation & 9 & 24.3 & 9 & 26.5 & $\begin{array}{l}0.8355 \\
\text { Chi2 }\end{array}$ \\
\hline $\begin{array}{c}\text { Barrett's esophageal } \\
\text { stump }\end{array}$ & 1 & 2.7 & 1 & 2.9 & $1.0000 \mathrm{~F}$ \\
\hline
\end{tabular}

$A=$ mechanical suture; $B=$ manual suture; $p=$ Fisher exact test Chi2 $=$ Chi-square test

\section{DISCUSSION}

Throughout the world surgical history, the stenoses, fistulas, and dehiscences resulting from anastomoses between viscera of the digestive system are justified by the fear of their presence, since they often evolve to excessive morbidity and not infrequently to death. Thus controversies over the best type of suture remains to the current days ${ }^{1,5,20,21}$.

Because the esophagus is the segment of the digestive tract that presents a higher incidence of dehiscences of anastomoses by the peculiarities already mentioned, it was necessary to use mechanical suture for the advantages it offers and reducing the frequency of this complication, especially in the cervical esophagus, as demonstrated in several series $1,5,8,14,18,19,30$. This fact became very evident in our study, since the patients from the mechanical suture group presented a significantly smaller incidence of dehiscence of the esophagogastric anastomosis in relation to the manual suture group, after esophageal mucosectomy.

Another fact to be considered is that the mechanical suture, for being double and inverted, could predispose stenosis of the esophagogastric anastomosis by up to three to five times in relation to manual, as has been demonstrated by several authors $1,4,15,19,20,31$. This is justified by the fact that most of the patients in related studies underwent esophagectomy due to cancer and therefore, presented a smaller diameter of the cervical esophageal stump to be anastomosed, so it became imperative to use staplers of smaller sizes. This fact was well evidenced a few years ago by Wong et al. ${ }^{33}$, when they correlated the staplers' diameter with the incidence of stenosis. These authors demonstrated that when they used devices with a diameter of $25 \mathrm{~mm}$, the incidence of stenosis was $25 \%$ and decreased to $12 \%$ with the use of staplers from 29-33 mm. Recently, Honda et al. ${ }^{14}$ have also demonstrated in a literature review comparing manual with mechanical suture in 1,407 patients undergoing esophageal anastomosis, a very adequate correlation between the stapler diameter and the degree of stenosis of the esophagogastric anastomosis.

Because the lumen of the esophageal stump to be anastomosed is greater in the advanced megaesophagus, it is possible to use devices with greater diameters, hence, reducing the incidence of stenosis. This was also evident in our study, since although this complication was present in patients from both groups, it was significantly smaller in patients who underwent mechanical suture, and this can be justified for having been used in all the circular device of number $29 \mathrm{~mm}$.

Another fact to remember is that of the 23 patients who presented stenosis of esophageal anastomosis, 14 (60.8\%) had previously fistula, and the relationship between anastomotic dehiscence and stenosis is frequent due to the fibrosis that occurs at the suture line after the anastomotic fistula closure, as has been demonstrated in several series $1,5,11,14,18,19$. Although there was a delay in the normal swallowing of these patients, they presented a positive progress after the endoscopic dilations and they reported being satisfied with the surgical procedure.

The performed technique of the esophageal mucosectomy with conservation of the muscular layer with the transposition of the stomach inside this layer was of great validity, as it avoided to transgress the mediastinum and thus prevented the potential lesions of the noble structures present there. Nevertheless, these complications are mentioned when the transmediastinal esophagectomy is used, and although not common, when they are actually present, there is a great potential for morbidity $8,19,22,23$. This situation has been proven in the patients of our series because none of them, from both groups, presented such complications at the mediastinal level, as the early assessment demonstrated. Nevertheless, some evolved to pleural effusion, but of low incidence in both groups and easily exited by conservative treatment and/or thoracic drainage.

Because esophageal mucosectomy is a major surgery and most patients from both groups are long-time smokers, it can be justified that eight patients presented pulmonary infection, and although there was specific clinical treatment, one in group $B$ evolved to death from septic shock. This has also been demonstrated in various series, when esophagectomy

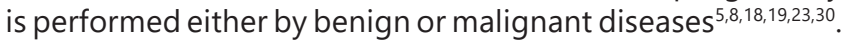

In the long-term evaluation with the average followup of 5.6 years in 71 patients, all of them reported being satisfied with the surgery, as $86 \%$ to $96 \%$ of them from both groups presented total recovery of swallowing with 4 and 5 Saeed et al. criteria ${ }^{28}$, which caused most of the patients to report weight gain and encourage them to return to their routine work activities. Although dysphagia for solid foods was present in some patients of both groups, this was not only intermittent, but also of low frequency and without significant differences between the groups.

The regurgitation was around $25 \%$ in both groups and was resolved after proper diet. This change is described in up to $50 \%$ in patients who undergo gastric transposition to replace the esophagus either by benign or malignant conditions ${ }^{3,4,5,6,8,18,19,20,23,30}$. This is usually a consequence of gastric stasis and if a proper diet is followed, the patients usually adapt well without compromising the usual activities.

Another fact to be remembered is that one patient from each group evolved in the late postoperative period with Barrett's esophagus in the esophageal stump. This change is usually a consequence of acid reflux and bile of the stomach transposed due to stasis, as has been demonstrated by some authors ${ }^{24,26,27}$. Although this complication was of low incidence, it needs to be considered due to the possibility of this compromised epithelium evolve to adenocarcinoma, as has already been demonstrated ${ }^{17,27}$. Hence, it is important to carry out a long-term follow-up with periodic digestive endoscopies, as recommended in these two patients in our study, or even the prolonged use of proton pump inhibitors to minimize reflux and its complications ${ }^{24,27}$.

A doubt that has always been present is that what could occur in the long-term assessment with these patients undergoing esophageal mucosectomy, whether the muscular layer of the esophagus at the level of the mediastinum could evolve to fibrosis with the consequent compression of the stomach and thus compromise the progress. The postoperative analysis, with an average follow-up time of 5.6 years in 71 patients showed that all of them progressed well, without presenting any symptoms that would suggest gastric compression.

And this fact was already evident in other studies performed by us, but with a smaller number of patients and with the cervical esophagogastric anastomosis performed only with manual suture and with imaging tests by thorax tomography, evidencing that the permanence of the muscular layer in the posterior mediastinum does not seem to have compromised the gastric transposition for reconstruction of the digestive tract after esophageal mucosectomy ${ }^{3,7}$. 
CONCLUSION

Esophageal mucosectomy with preservation of the muscular layer for the treatment of advanced megaesophagus is adequate procedure, due to the low rate of pleuropulmonary complications, absence of mediastinal complications and adequate recovery of swallowing in the majority of long-term follow-up. The mechanical suture of the cervical esophagogastric anastomosis is more adequate because it presents significant lower incidence of anastomotic complications than the manual technique.

ORCID

José Luis Braga de Aquino: 0000-0002-0604-9054

Vania Aparecida Leandro-Merhi: 0000-0003-2859-0228

José Alexandre Mendonça: 0000-0003-1689-6705

Elisa Donalisio Teixeira Mendes: 0000-0003-4251-8185

Conceição de Maria Aquino Vieira Clairet: 0000-0001-5889-8149

Leonardo Oliveira Reis: 0000-0003-2092-414X

\section{REFERENCES}

1. AquinoJLB, Camargo JGT, SaidMM, Palu B, Leandro-Merhii,VA. Avaliação daanastomoseesofagogastricacervical comsuturamecânicaemanualem pacientescommegaesofagoavançado. RevCol Bras Cir.2009;36(5):19-23

2. Aquino JLB, Chagas JFS, Said MM, Pascoal MBN, Pereira DAR, LeandroMerhii VA. Early and late assessment of the surgical treatment of the pharyngoesophageal diverticulum by mechanical and manual suture. Otorhinolaryngol Head Neck Surg. 2017; 2(2):1-4.

3. AquinoJLB, SaidMM, CamargoJGT.Non-conventional surgicalapproach toachalasia:mucosectomyandendomuscularpull-through.Mini-invasive Surg. 2017;1:167-72.

4. Aquino JLB. Anastomose esofagovisceral: sutura manual ou mecânica? Quando a sutura mecânica é realmente vantajosa? ABCD Arq Bras Cir Dig. 1997;12(1):75-77.

5. Aquino JLB. Avaliação da anastomose esofagogástrica cervical com sutura mecânica em pacientes com megaesôfago avançado. Rev Col Bras Cir. 2005;32(3):143-6.

6. Aquino JLB, Reis Neto JA, Muraro CPM, Camargo JGT. Mucosectomia esofágica no tratamento do megaesôfago avançado: analise de 60 casos. Rev Col Bras Cir. 2000;27:109-16.

7. Aquino JLB, Said MM, Fernandes PR. Avaliação tardia da mucosectomia esofagica com conservação da túnica muscular em pacientes com megaesôfago avançado. Rev Col Bras Cir. 2007;34(1):19-25.

8. AquinoJLB, SaidMM,Leandro-MerhiVA, IsdchioneL, RamosJLZ, Guimaraes DM. Análise das complicações da esofagectomia transmediastinal no tratamento cirúrgico do megaesôfago recidivado. ABCD Arq Bras Cir Dig. 2011;24(1):20-4.

9. Aquino JLB, Said MM, Leandro-Merhi VA, Nardini GC, Gallo E, Assunção M. Avaliação da terapêutica cirúrgica do Divertículo Faringo esofágico com sutura mecânica. Arq Bras Cir Dig. 2012; 25(2):34-9.

10. Aquino JLB, Said MM, Pereira EVA, Kelmann BV, Oliveira MB. Tratamento cirúrgico do megaesôfago recidivado. Rev Col Bras Cir. 2007:34(5):310-3.

11. CaparossiC,Ceconellol,Aguilar-NascimentoJE, VençoF, Gama-Rodrigues JJ. Hand-sewn and stapled esophageal anastomosis: Experimental study in dogs. Acta Cir Bras. 2004;19(4):286-91.

12. Crema E, Ribeiro LBP, Souza RC, Terra Junior JÁ, Silva BF, Silva AA et al. Esofagectomiatranshiatallaparoscopcaparaotratamentodomegaesôfago avançado: Análise de 60 casos. Rev Col Bras Cir. 2009,36(2):118-22.
13. Fontan AJA, Batista-Neto J, Pontes ACP, Nepomuceno MC, Muritiba TG, Furtado RS. Minimally invasive laparoscopic esophagectomy vs. transhiatal open esophagectomy in achalasia: a randomized study. ABCD Arq Bras Cir Dig. 2018;31(3):e1382.

14. Honda M, Kariyama A, Noma H, Nunobe S, Furkawa T. Hand-sewn versus mechanical esophagogastric anastomosis after esophagectomy: a systematic review and meta-analysis. Ann Surg. 2013;257:238-48.

15. Hsu HH, Chen JS, Huang P. Comparison of manual and mechanical cervical esophagogastric anastomosis after esophageal resection for squamous cell carcinoma: a prospective randomized controlled trial. Eur J Cardiothorac Surg. 2005;25(6):1097-101.

16. Lopes LP, Menezes TM, Toledo DO, De-Oliveira ATT, Longatto-Filho A, Nascimento JEA. Early oral feeding postupper gastrointestinal tract resection and primary anastomosis in oncology. ABCD Arq Bras Cir Dig. 2018;31(1):e1359.

17. Oberg S, Joahansson J, Wenner J, Walther B. Metaplastic columnar mucosa in the cervical esophagus after esophagectomy. Ann Surg. 2002; 235(3):338-45

18. Okuyama M, Moyama S, Suzuki, M. Handsewn cervical anastomosis versus stapled intrathoracic anastomosis after esophagectomy for middle or lower thoracic esophageal cancer: a prospective randomized controlled study. Surg Today. 2007;379(11):947-52.

19. Orringer MB, Marshall B, Chang AL, Lee J, Pichens A, Lau C. Two thousand transhiatal esophagectomies: changing trends, lessons learned. Ann Surg. 2007;24:363-7.

20. OrringeMB,MarshallB, lannettoMD. Eliminatingthecenvicalesophagogastric anastomosisleakwithaside-sidestapledanastomosis.JthoracCardiovasc Surg. 2000;119: 227-38.

21. Orsi F, Carvalho G. A fistula esofagogastrica cervical. Rev Col Bras Cir. 2003:30(1):16-20.

22. Pinotti HW. Esofagectomia subtotal por túnel transmediastinal sem toracotomia. Rev Ass Med Bras.1997; 23:395-8

23. PinottiHW, Zilberstein B, PollaraW, Ceconellol. Esophagectomy without thoracotomy. Surg Gynecol Obstet.1981;152:344-6.

24. PochiniCC, GagliardiD, Saad JuniorR,AlmeidaRF, CorsiPR. Esofagectomia comgastroplastia nomegaeosfagoavançado:analisetardiadaimportância do uso do omeprazol. Rev Col Bras Cir. 2015;42(5):299-304.

25. Rezende JM, Lauar KM, Oliveira AR. Aspectos clínicos e radiológicos da aperistalse do esôfago. Rev Bras Gastroenterol. 1960; 12:247-51.

26. Rocha JM, Ribeiro U, Cecconello I, Sallum RA, Takeda F, Nasi A. Gastric secretory and hormonal patterns in end- stage chagasic achalasia. Dis Esophagus. 2009;22(7):606-10.

27. Rocha JM, Ribeiro U, Sallum RA, Szachnowicz S, Cecconello I. Barrett's esophagus(BE) and carcinoma in the esophageal stump (ES) after esophagectomy with gastric pull- up in achalasia patients: a study based on 10 years follow-up. Ann Surg Oncol. 2008:15(100):2903-9.

28. SaeedZA, WinchesterCB,FerroPS, MichletzPA, SchwartzDYG.Prospective randomized comparison of polyvinyl bougies and through the scope balloons for dilation of peptic strictures of the esophagus. Gastrointest Endosc. 1995;41:189-95

29. Smithers BM, Gotley DC, Martin JM. Comparison of the outcomes between open and minimally invasive esophagectomy. Ann Surg. 2007;24(2):232-40.

30. UrschelJD, BlewettCJ, BennetWF. Hand-sewnorstapledesophagogastric anastomosis afteresophagectomyforcancer.Metaanalysisofrandomized controlled trials. Dis Esophagus. 2001;14(3-4): 212-7.

31. ValverdeA, HayJM,FingerhutA.Manualversusmechanicalesophagogastric anastomosis after resection for carcinoma: a controlled trial. French Associations for Surgical Research. Surgery.1996;120 (3):476-83.

32. Wheeless CR, Smith JJ. A comparison of the flow of iodine 125 through threedifferentanastomosis:standard,gambee, staple. Obstetric Gynecol. 1993:62(4):513-8.

33. Wong J, Cheung HLUI. Esophagogastric anastomosis performed with a stapler.theoccurrenceofleakageandstricture.Surgery.1987;101(4):408-15. 